\title{
Remittances, Monetary Institutions, and Autocracies
}

\author{
Ana Carolina Garriga \\ Department of Government, University of Essex \\ (carolina.garriga@essex.ac.uk) \\ Covadonga Meseguer*** \\ Department of International Relations, London School of Economics \& Political Science \\ (covadonga.meseguer@gmail.com)
}

How do remittances affect the choice of exchange rate regimes? Previous research shows that remittances, by easing the "impossible trinity", increase the probability of governments adopting fixed exchange rates. However, that research overlooks the conditioning effect of monetary and political institutions. We argue that remittances, by altering recipient governments' incentives to use monetary policy counter-cyclically, make central bank independence a credible anti-inflationary tool in less credible regimes; that is, autocracies. Thus, autocracies that receive remittances do not need to rely on fixed exchange rates. In this way, remittances open policy alternatives for developing autocracies. Statistical tests on a sample of 87 developing and transitional countries between 1980 and 2010 support our argument.

Keywords: remittances; central bank independence; exchange rate regimes; autocracies; developing countries.

*** Corresponding Author

Previous versions of this paper were presented at the 2016 Annual Meeting of the American Political Science Association; at the workshop "New Directions in IPE," CIDE, Mexico City, October 6, 2016; at the $58^{\text {th }}$ Annual Convention of the International Studies Association February 22-25, 2017, Baltimore, MA; and at the $75^{\text {th }}$ Midwest Political Science Association Annual Convention, April 6-9, 2017, Chicago, IL. We thank participants at those events; Eric Arias, Lucy Goodhart, Sebastián Lavezzolo, Michael Miller, David Singer, David Steinberg, and two anonymous reviewers for their comments. We also thank Lilian Medrano and Pascal Jaupart for excellent research assistance. 


\section{Introduction}

In 2016, expatriates sent back home 429 billion dollars, second only to foreign direct investment as a source of foreign income for developing countries (World Bank, 2017). The magnitude of these flows and their stability relative to other private capital inflows, justify the growing interest in understanding the political and economic consequences of remittances (Combes, Ebeke, \& Maurel, 2015; World Bank, 2006). Recent research sheds light on some effects of remittances on domestic and global governance, in issues that range from moral hazard (Ebeke, 2012) to corruption (Abdih, Chami, Dagher, \& Montiel, 2012; Tyburski, 2012, 2014), foreign aid policy choices (Bermeo \& Leblang, 2015), and foreign direct investment (Leblang, 2010). However, we know less about the effect of remittances on the choice of exchange rate regimes.

A significant body of literature analyses how financial internationalisation and capital movements may constrain domestic policy options (Dion, 2009; Garrett \& Lange, 1991; Rudra, 2002). In contrast, this paper shows ways in which remittances may make certain policy options available in institutional contexts often encountered in developing countries. In particular, we study the effect of remittances on the choice of exchange rate regimes, a policy with profound repercussions both on countries' domestic economies and their foreign economic relations (Frieden, 1991, 2015). Although remittances do not accrue to governments directly, they have the potential to alter incumbents' incentives to adopt different economic policies. In this paper, we argue that remittances allow governments to adopt less costly, more flexible exchange rate arrangements, while credibly committing to controlling inflation. This effect, however, depends on the country's monetary and political institutions, as already suggested by Bernhard et al. (2002) and others.

There are two ways through which remittances can affect exchange rate regimes. First, the stability and anti-cyclicality of remittances can mitigate the costs of adopting fixed exchange rates. Thus, remittances should increase the probability of observing fixed exchange rates, as suggested 
in Singer (2010). In this author's account, the effect is not mediated by political regime or other monetary institutions. In contrast, we focus on the conditioning effects of political and monetary institutions, and propose that under some circumstances, the stability and anti-cyclicality of remittances should enhance the credibility of central bank independence (CBI) as an antiinflationary tool, and reduce the need to rely on fixed exchange rates. We argue that this effect is especially relevant in autocracies, where the credibility of CBI is more easily compromised (Broz, 2002). Thus, the scope conditions of this credibility effect are both the existence of an independent central bank and less transparent regimes (autocracies). We find that in autocracies with independent central banks, remittances are associated with a greater likelihood of observing flexible exchange rate regimes.

This paper bridges two literatures. On one hand, studies on the impact of international migration show that remittances have significant effects on national economies, with consequences for a wide range of development outcomes (Abdih et al., 2012; Ahmed, 2012; Combes \& Ebeke, 2011; Escribà-Folch, Meseguer, \& Wright, 2015). On the other hand, research on the choice of exchange rate regimes and monetary institutions under capital mobility indicates that the choice of monetary and exchange rate arrangements cannot be thought of as independent of each other (Bearce, 2002, 2008; Bernhard et al., 2002; Bodea, 2010). Only a few studies have sought to connect these two literatures (Mandelman, 2013; Singer, 2010). However, these studies do not discuss the interactions between exchange rate regimes and $\mathrm{CBI}$ in the presence of remittances, nor do these works discuss the potential diverging effects in different types of political regimes (Bearce, 2014; Leblang, 2003; Steinberg \& Malhotra, 2014). Accounting for these interactions provides a better understanding of the scope conditions that shape the effect of remittances on the choice of exchange rate regime in developing countries.

We contribute to a growing literature showing that although remittances bypass incumbents, they have profound implications for home countries in policies as diverse as social spending (Doyle, 2015; Easton \& Montinola, 2017 ), diaspora engagement (Leblang, 2017), and 
debt sustainability (Chami et al., 2008). We also contribute to new research showing that country institutional characteristics may affect the constraining effects of the "impossible trinity" (Barajas, Chami, Ebeke, \& Oeking, 2016; Rey, 2015, 2016). ${ }^{1}$

The paper proceeds as follows. The following section provides the background on the choice of monetary institutions. Next, we review the role of remittances in affecting the credibility of different monetary instruments. Following this discussion, we derive our main testable hypothesis. We then present the data and methods, and discuss our findings. We finish with a conclusion and propose further steps for research.

\section{The Political Economy of Exchange Rate Regimes}

The "impossible trinity" posits that governments can simultaneously achieve only two out of three desirable policy outcomes: high capital mobility, stable exchange rates, and an autonomous monetary policy (Fleming, 1962; Mundell, 1961). In the post-Bretton Woods era, characterised by the removal of capital controls, the trilemma is reduced to the choice between enjoying exchange rate stability or an autonomous monetary policy (Obstfeld, Shambaugh, \& Taylor, 2005; Rey, 2015). We should observe floating exchange rates in countries that prefer the ability to respond to recessions or economic shocks. In contrast, countries that prioritize the stability of their foreign economic relations, or that need to signal commitment to price stability, could be expected to choose fixed exchange rates - and forfeit monetary autonomy.

We focus on one of these important roles that fixed exchange rate regimes play, especially relevant for developing countries: backing anti-inflationary or orthodox monetary commitments. To control inflation - and to signal commitment to this policy goal - countries

${ }^{1}$ We are able to examine empirically the effect of regime type in this context thanks to newly released data on legal central bank independence. These data allow our study to include a significant number of autocracies excluded from previous analyses (Garriga, 2016). 
can either fix their exchange rate or increase $\mathrm{CBI} .{ }^{2} \mathrm{CBI}$ is less costly than fixed exchange rates because it does not imply giving up monetary policy for stabilisation purposes (Obstfeld \& Rogoff, 1995, p.74). However, a government's commitment to respecting CBI is also less transparent: it is harder to learn whether the government imposes its preferences over the central bank board than to observe deviations from a fixed exchange rate (Broz, 2002). This reduced ability to observe compliance may affect the credibility of the commitment. Here, regime type matters. Democracies can rely on the regime's credibility and commit to price stability through institutional mechanisms. Autocracies cannot credibly commit to respecting CBI (Broz, 2002). Therefore, they should rely on a costlier commitment technology to control inflation, namely, fixed exchange rates. ${ }^{3}$

We argue that remittances may enable autocracies to use CBI to signal their commitment to price stability. Holding constant other incentives to adopt different exchange rate regimes, we argue that remittances alter the incentives to adopt a fixed exchange rate in the presence of an independent central bank. ${ }^{4}$

${ }^{2}$ Fixed exchange rates and independent central banks are institutional mechanisms that provide credibility to price stability commitments. For a careful discussion of the limits of these mechanisms, and the possible need to rely on both of them, or the limits, see Bodea (2010).

${ }^{3}$ Note that credible central bank independence is considered to have other functions similar to fixed exchange rates. In non-OECD countries, central bank independence may attract foreign direct investment, and guarantee better conditions in credit markets (Bodea \& Hicks, 2015a).

${ }^{4}$ A significant body of literature explains the distributive pressures to enact fixed exchange rates (Frieden, 2015). In particular, domestic sectors that profit from international trade or payments such as exporters - support fixed exchange rates (Frieden, 1991). However, the cost of sustaining fixed exchange rates is high for governments, who lose the ability to respond to economic downturns, and for consumers, who are generally domestically oriented (Bearce \& Tuxhorn, 2017). We control for sectoral pressures in our empirical analysis. Future research could also theorize about remittance recipients as another societal group with specific exchange rate preferences. 


\section{Remittances, Central Bank Independence, and Exchange Rates}

Remittances are a more stable source of foreign revenue than other capital flows, such as private portfolio investment. Furthermore, remittances are sent counter-cyclically, increasing during adverse economic conditions, natural catastrophes, and during war and conflict in home countries (Frankel, 2011; World Bank, 2006; Yang \& Choi, 2007). Thus, remittances have an income smoothing effect that performs an insurance role, helping families to weather adverse economic times (Combes \& Ebeke, 2011). Through remittances, migrants often become nonstate providers of public goods at the local level (Adida \& Girod, 2011; Aparicio \& Meseguer, 2012; Duquette-Rury, 2014), easing demands on governments to provide public and social goods.

Numerous studies across different regions provide evidence of a substitution effect by which households invest substantial amounts of the money they receive from relatives abroad on education and health, as well as on other investments such as housing or starting private businesses (Adams \& Cuecuecha, 2010; Ebeke \& Drabo, 2011). Through a variety of channels, remittances reduce poverty (Adams \& Page, 2005; Fajnzylber \& López, 2008; World Bank, 2006), making it less pressing overall for governments to invest in social policies as recipients' autonomy from the state increases (McMann, 2006). Ahmed $(2012,2013)$ and Easton \& Montinola (2017) document that as a result of the substitution effect of remittances, autocracies that receive remittances spend less on social transfers and more on patronage and military spending. ${ }^{5}$ Doyle (2015) shows that Latin American governments have reduced social spending as a result of remittances, partly due to the change in preferences for redistribution among remittance recipients, away from higher taxation. Also, while remittances are rarely directly taxed,

\footnotetext{
${ }^{5}$ Easton \& Montinola (2017) find that in democracies, remittances complement rather than substitute for government spending.
} 
they increase household consumption and provide an extra source of revenue for governments via indirect taxation (Chami et al., 2008; Ebeke, 2014). ${ }^{6}$ Bugamelli \& Paterno (2009) show that remittances above $3-4 \%$ of GDP contribute to financial stability by lowering the probability of current account reversals. This is because the stable and low-cyclical character of remittances can enhance countries' credibility in international markets in terms of debt sustainability. Remittances also improve countries' credit ratings (Avendano, Gaillard, \& Nieto-Parra, 2011; Chami et al., 2008:72; Ncube \& Brixiova, 2013; World Bank 2006). Through all these channels, remittances improve the overall economic outlook of the countries that receive them, and make it less pressing for governments to intervene in the event of economic slowdown. Unsurprisingly, many governments in outmigration countries reach out to their diasporas to entice those abroad to invest in their communities of origin through co-production schemes as a way to expand their budgets (Aparicio \& Meseguer 2012; Duquette-Rury 2014). ${ }^{7}$

${ }^{6}$ Public financing of chronic fiscal deficits is generally considered a major cause of inflation in developing countries. It could then be argued that the relevant mechanism by which remittances may enhance the credibility of these countries is by making that financing less pressing. However, remittances being private funds, it is not simple to anticipate their consequences on fiscal consolidation: remittances indirectly affect government expenditures and revenues depending on households' decisions to save or spend, and remitters' spending on welfare and public goods, which can complement or substitute for public spending (Gnangnon, 2014, pp. 171-172). We gave a number of examples above showing that remittances seem to substitute for government spending in welfare policies. Gnangnon shows that in a group of the top 30 remittance-dependent countries, remittances are associated with a greater probability of fiscal consolidation. The author does not account for regime type.

${ }^{7}$ There are of course other cases of more intrusive meddling with international remittances. For instance, Lim \& Morshed (2017, p. 148) provide the examples of (now abolished) Documentary Stamp Tax of 0.3 pesos for every 200 pesos in Philippines. Cuba levied a $10 \%$ tax on all remittance in US dollars through the exchange rate; India unsuccessfully proposed a tax of $12.36 \%$ on fees remitters pay to send money home. On the whole, taxing remittances directly is hugely unpopular and generally considered to promote the use of informal channels of remittance transfers. 
Based on this compensatory logic of remittances, Singer argues that because remittances "mitigate the costs of forgone domestic monetary policy autonomy," they should increase the likelihood that policy makers adopt fixed exchange rates (Singer, 2010, p. 307). In other words, in a context of capital mobility, remittances help ease the trilemma by decreasing the need for an autonomous monetary policy. Singer finds that remittances (unconditionally) increase the likelihood of having fixed exchange rates in developing countries.

This account, however, is not clear regarding why all governments would prefer to tie their hands with a fixed exchange rate. ${ }^{8}$ First, if a government needs to signal their antiinflationary commitment - a frequent concern in developing countries - CBI is a less costly mechanism that can deliver similar results. Secondly, assuming that all governments prefer fixed exchange rates is at odds with the fact that fixed exchange rates are especially onerous for countries with high exposure to volatile capital flows, or highly dependent on them (Fernandez, Karacadag, \& Duttagupta, 2004; Rogoff, Husain, Mody, Brooks, \& Oomes, 2004). When remittances represent an important source of foreign revenue, incumbents may want the flexibility to adjust their monetary policy in the event of adverse economic shocks in the host economies, something that fixed exchange rates preclude. Finally, in contrast with Broz (2002), such an unconditional account of the choice of exchange rate regimes implies that all political regimes are in the same position when it comes to choosing between monetary and exchange rate commitments.

These arguments point out powerful reasons to adopt flexible exchange rate regimes in developing countries, and to commit to price stability through less costly tools, such as CBI. Yet for countries with inflation concerns, flexible exchange rates are an option only if monetary commitments are credible. Because remittances are relatively stable and counter-cyclical,

\footnotetext{
${ }^{8}$ For instance, electoral incentives should make democracies more likely to prefer floating exchange rates (Bearce \& Hallerberg, 2011; Frieden, 1991; Steinberg \& Malhotra, 2014)
} 
remittances can make the commitment to central bank independence more credible through the same compensatory logic we laid out above.

We further contend that this effect is especially important for political regimes suffering from a credibility deficit (Broz, 2002). ${ }^{9}$ Generally speaking, commitments to CBI in democracies are credible because of the transparency of democratic institutions and decision-making processes (Broz, 2002). In contrast, commitments made by autocracies are more vulnerable to changes in the autocrats' wills. Because of their countercyclical character, remittances may alter the autocrats' incentives to pressure independent central bankers. ${ }^{10}$ If, as we contend, remittances allow autocrats to choose between $\mathrm{CBI}$ and fixed exchange rate regimes, we should observe a substitution effect between independent central banks and pegs because $\mathrm{CBI}$ is a less costly commitment technology.

It is important to emphasise that autocracies with independent central banks are not rare. On a worldwide sample between 1970 and 2012, about 40\% of observations in non-democratic regimes (Polity2 <7), and 49\% in democracies have independent central banks (Garriga, 2016). ${ }^{11}$ To illustrate, consider the cases of Armenia and Mexico. These countries are highly dependent on remittances, both in absolute and in relative numbers, have flexible exchange rate arrangements, and independent central banks (Banaian, Kemme, \& Sargsyan, 2008; Ruiz \& Vargas-Silva, 2010, p. 174). When they adopted floating exchange rate regimes, both countries were autocracies that had granted independence to their central banks. Studies that explore the

${ }^{9}$ We assume that all autocracies have credibility problems because their lack of transparency hampers the credibility of their monetary commitments (Broz, 2002). Some democratic countries may also have credibility problems due to other reasons, but analysing variance of credibility among democracies is outside the scope of this paper.

${ }^{10}$ This expectation is consistent with research showing that central banks also have significant effects in autocratic regimes (Baerg, Gray, \& Willisch, 2017; Bodea, Garriga, \& Higashijima, 2019).

${ }^{11}$ We consider a central bank independent when it scores $\geq .5$ on an index that ranges from zero to one. 
adoption of inflation targeting in these countries point out the important role that remittances play in dealing with balance-of-payments imbalances (Ruiz \& Vargas-Silva, 2010; Van Aarle \& Sosoian, 2010). Furthermore, anecdotal evidence shows that their central banks were well aware of the importance of remittances (Ruiz \& Vargas-Silva, 2010).

Note that our argument does not imply any prior assumption about the temporal sequence in the choice of monetary instruments. We claim that we are likely simultaneously to observe remittances and flexible exchange rate regimes in autocracies, but only in the presence of an independent central bank. We take the temporal precedence of $\mathrm{CBI}$ and exchange rate regime as an empirical matter. Nor does our argument imply any assumption about the relationship between receiving remittances and the probability of granting more independence to the central bank. ${ }^{12}$ We merely contend that receiving remittances makes independent central banks more credible in their price stability commitment via reduced pressure for social and public spending and through a better appraisal of a country's ability to meet international commitments. ${ }^{13}$

In sum, we contend that in previous research, the mediating role of political regimes and CBI has not been fully spelled out. We argue that the same compensatory character of remittances makes CBI credible, and that this effect is relevant in autocracies. As a result, we expect autocracies that receive remittances and grant independence to their central banks to have

${ }^{12}$ In fact, we do not find any robust evidence in that regard. To address this question, we use the model specification of Bodea \& Hicks (2015a) for central bank reform, and test the existence of a relationship between remittances - measured in different ways - and level of central bank independence. We do not find significant relationships between past levels of remittances and central bank independence in the global sample, or in subsamples of democracies and autocracies.

${ }^{13}$ Note that in autocracies, remittances may support the adoption of flexible exchange rates beyond strengthening the credibility of independent central banks as a price stability commitment. Like independent central banks, remittances also facilitate access to international capital markets (Bodea \& Hicks, 2015a). Thus remittances, by improving the credibility of countries to honour their debt commitments, make independent central banks credible anti-inflationary tools. 
flexible exchange rate regimes without compromising their commitment to low inflation. This effect of remittances should not be observed in autocracies that do not grant independence to their central banks. Further, given that democracies can rely on their institutions' transparency to substitute fixed exchange rate regimes for independent central banks (Bodea \& Hicks, 2015b; Broz, 2002; Clark, 2002), the mechanism of enhanced CBI credibility through remittances should not matter in democracies.

From the discussion above, we derive the following testable hypothesis: In autocracies with independent central banks, remittances increase the probability of observing floating exchange rates.

\section{Data and Models}

We test our argument on a sample of developing countries between 1981 and 2010. The sample size is restricted by data availability. The dependent variable is the de facto exchange rate regime. Following the literature on exchange rate regimes (e.g., Bearce \& Hallerberg, 2011; Frieden, 2015; Singer, 2010; Steinberg \& Malhotra, 2014), we use Reinhart and Rogoffs (2004) updated data. Exchange rate regime is a categorical variable ranging from 1 (fixed) to 4 (floating). 48 percent of the observations in our sample are coded as fixed exchange rates (1); 27 percent as crawling pegs or bands (2). Managed floats (3), and free-floating regimes (4) represent 21 and 4 percent of our sample respectively. The use of the four-category variable allows us to account for different degrees of "hardness of the peg" (Meissner \& Oomes, 2009) $\cdot{ }^{14}$ Further, this fourcategory variable also allows us to address the fact that many developing countries have opted

\footnotetext{
${ }^{14}$ Following other studies on exchange rate regimes (Chiu \& Willett, 2009; Simmons \& Hainmueller, 2005; Singer, 2010; Steinberg \& Malhotra, 2014), we exclude observations classified as freely falling and dual market in which parallel data is missing (categories 5 and 6 in Reinhart \& Rogoff's (2004) coarse classification). These two cases are considered as distinct from the floating-pegging continuum (Meissner \& Oomes, 2009). This decision excludes 102 observations from our analyses.
} 
for what Aizenman (2018: 1) describes as mixed regimes or a "trilemma middle ground" described by a combination of "managed exchange rate flexibility, controlled financial integration, and viable but limited monetary independence." ${ }^{15}$ Figure A1 in the Supplementary Appendix shows the distribution of exchange rate regimes in our sample by regime type.

We measure remittances as the country's yearly inflows in constant dollars, logged and lagged. The data comes from the World Development Indicators (WDI) of the World Bank (2015). We prefer this measure to the frequently used remittances as percentage of the country's GDP because remittances impact the recipient country's growth (Escribà-Folch et al., 2015) this may in turn affect the interpretation of our results, underestimating the actual impact of remittances. Nonetheless, we use alternative measures of remittances (both remittances as a percentage of GDP, and remittances in constant dollars per capita) as robustness checks (Supplementary Appendix, Table A3).

We use Garriga's (2016) measure of CBI, based on Cukierman, Webb, and Neyapti (1992). The index ranges from 0 (lowest) to 1 (highest independence), and weighs legal characteristics of the central bank's governor (appointment, dismissal, and term of office); policy formulation attributions (who formulates and has the final decision on monetary policy, and the role of the central bank in the budget process); the central bank's objectives; and the central bank's limitations on lending to the public sector (Garriga, 2016, p. 854).

As mentioned, autocracies do grant legal independence to their central banks, and there is a significant variance in CBI across autocracies. Although it is beyond the scope of this article

${ }^{15}$ These regimes became prevalent following successive financial crisis in emerging markets and more recently in the U.S. and the Eurozone area. This period has witnessed a progressive shift in views regarding the viability and pertinence of capital controls as well as the use of precautionary measures (such as the accumulation of international reserves) to tackle financial instability - transforming the trilemma into a quadrilemma once financial stability is also added to the picture (Ainzenman, 2018). 
to analyse this in detail, there are various reasons that could explain central bank independence in autocracies. Boylan $(1998,2001)$ sees central bank independence under Pinochet's rule as a way to tie the hands of future administrations. Other explanations include signalling creditworthiness to international markets (Maxfield, 1997), attempts to deflect responsibility for poor economic outcomes (Bodea et al., 2019), learning and competition (Bodea \& Hicks, 2015a), norm diffusion (Johnson, 2016; McNamara, 2002), or power-sharing agreements (Baerg et al., 2017; Bodea et al., 2019). Figure 1 shows the distribution of CBI among democracies and autocracies in our sample. Democracy is defined as Polity2 $\geq 6$ (Marshall \& Jaggers, 2012). The mean CBI for democracies is .54 , and .48 for autocracies. There are 951 observations of authoritarian regimes with independent central banks (CBI $\geq .5)$.

Figure 1: Central bank independence in developing countries, by regime type (1981-2010)
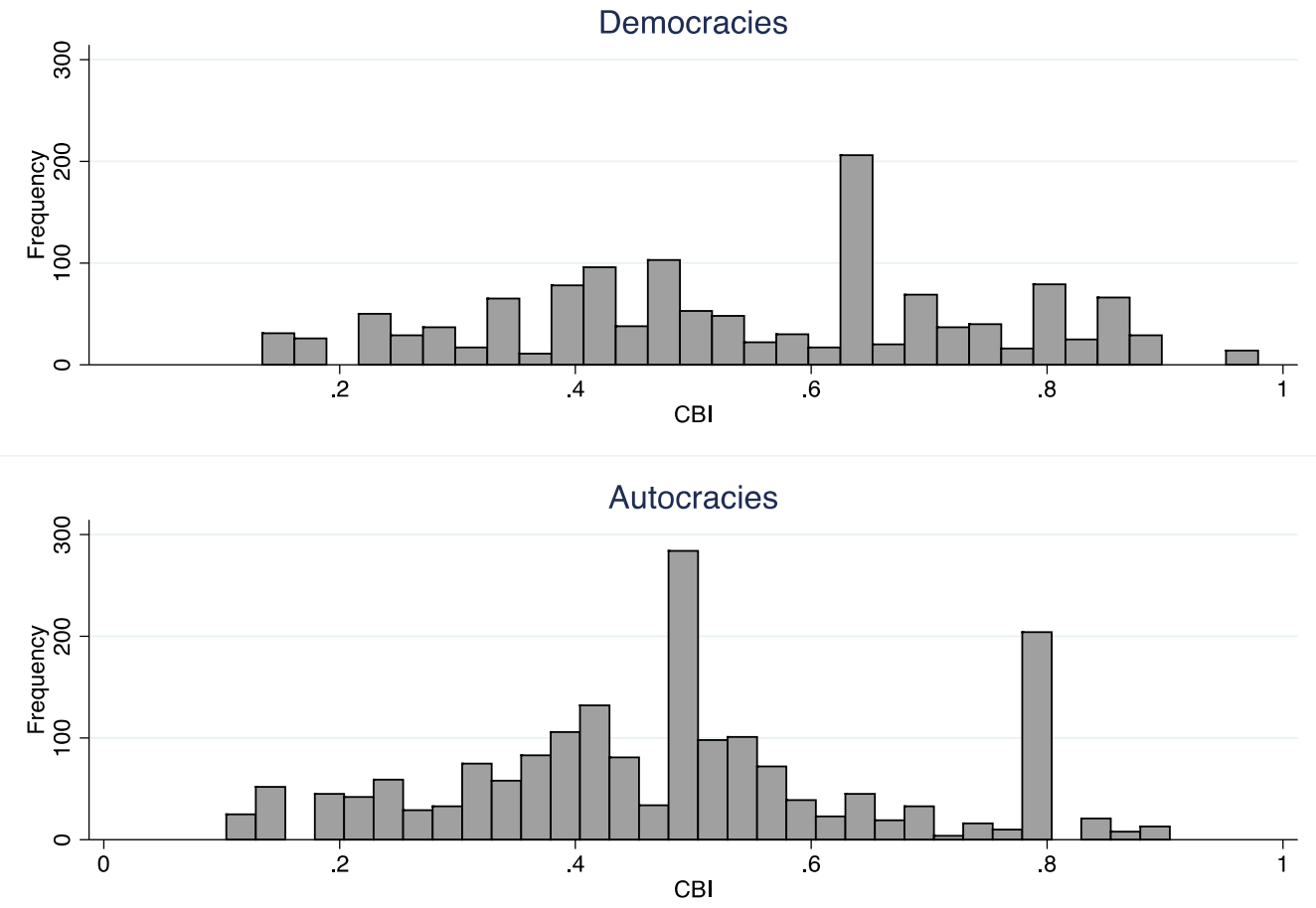
Our theory contends that the impact of remittances on the choice of exchange rate regime is conditional on the political regime and on monetary institutions. Testing this hypothesis entails using a triple interaction. For ease of interpretation, we include an interactive term between remittances and CBI, and explore the effect of this interaction in subsamples of autocracies and democracies as defined above.

We control for other variables typically included in models of exchange rate regime choices. Following Singer's (2010) specification, our models include the lagged dependent variable, the natural log of GDP and GDP per capita, exports as percentage of GDP, reserves in months of imports, trade volatility (the standard deviation on $t, t_{-1}$ and $t_{2}$ on net barter terms of trade), inflation (logged), and current account balance. We include the size of manufacturing relative to the GDP as a control for sectoral explanations of exchange rate regime choices. Since population also influences the volume of remittances received, we control for the country's population (logged and lagged). These data come from WDI (World Bank, 2015). We also control for capital account openness (Chinn \& Ito, 2008) to account for the fact that governments still use this policy tool and for regime type using Polity2 (Marshall \& Jaggers, 2012). Lagged variables are indicated in the tables.

We run ordered probit models, clustered on country, on a sample of 87 developing countries between 1981 and 2010. ${ }^{16}$ Given the panel structure of the data, where subscripts $i$ and $t$ represent country and year respectively, and that the dependent variable is categorical (the outcomes are represented by 0 , and the cutpoints by $k$ ), our baseline specification is:

$\operatorname{Pr}\left(\mathrm{ERR}_{o}=j\right)_{i t}=\operatorname{Pr}\left(k_{j-1}<\beta_{1} \ln \left(\text { remitt }_{i-1}\right)+\beta_{2} \mathrm{CBI}_{i t-1}+\beta_{3}\left[\ln \left(\text { remitt }_{i-1}\right) * \mathrm{CBI}_{i t-1}\right]+\gamma_{1} X_{i t-1}+\varepsilon_{i t} \leq k_{j}\right)_{i t}$

\footnotetext{
${ }^{16}$ See Table A1 for the list of countries included in the analysis. See Table A2 for descriptive statistics.
} 
Recall that the dependent variable is categorical, with greater values indicating a more flexible exchange rate regime. In autocracies, we expect $\beta_{1}<0$, as this is the effect of remittances on the probability of having more flexible exchange rate regimes when CBI is zero (Singer, 2010). We expect $\beta_{2}<0$ because in the absence of remittances, CBI is not a credible substitute for fixed exchange rates in autocracies (Broz, 2002). However, we expect $\beta_{3}>0$, indicating that the effect of remittances on the probability of having a flexible exchange rate regimes increases as CBI increases.

\section{Results}

Table 1 presents the test of our argument. Column 1 shows the results of the baseline model on a sample that pools autocracies and democracies. In the full sample, the combined coefficient (marginal effect of remittances) is positive and marginally statistically significant, indicating that remittances increase the likelihood of countries adopting more flexible exchange rates. ${ }^{17}$ This weak result is not surprising, given the expected diverging effects of these variables in different institutional contexts and the greater number of country/year observations under autocracy. Columns 2 and 3 present the results for the same models on subsamples of autocracies and democracies.

${ }^{17}$ However, as we show in models on sub-samples of autocracies and democracies, the result in the pooled sample seems to be driven by autocracies. 
Table 1. Ordered probit estimations of de facto exchange rate (four-category dependent variable)

\begin{tabular}{|c|c|c|c|}
\hline $\begin{array}{l}\text { Model and } \\
\text { Sample }\end{array}$ & $\begin{array}{c}\text { (1) } \\
\text { All developing countries }\end{array}$ & $\begin{array}{c}\text { (2) } \\
\text { Autocracies }\end{array}$ & $\begin{array}{c}\text { (3) } \\
\text { Democracies }\end{array}$ \\
\hline Remittances (in constant US $\$, \log )_{t-1}$ & $\begin{array}{l}-0.0663 \\
(0.0666)\end{array}$ & $\begin{array}{l}-0.164 * * \\
(0.0750)\end{array}$ & $\begin{array}{c}0.0247 \\
(0.0853)\end{array}$ \\
\hline Central Bank Independence $(\mathrm{CBI})_{\mathrm{t}-1}$ & $\begin{array}{l}-3.401^{*} \\
(1.950)\end{array}$ & $\begin{array}{c}-7.254^{* * * *} \\
(2.241)\end{array}$ & $\begin{array}{l}0.293 \\
(2.361)\end{array}$ \\
\hline $\begin{array}{l}\text { Remittances (in constant US } \$, \log )_{\mathrm{t}-1} \\
{ }^{*} \mathbf{C B I}_{\mathrm{t}-1}\end{array}$ & $\begin{array}{c}0.177 \\
(0.118)\end{array}$ & $\begin{array}{c}0.425^{* * *} \\
(0.139)\end{array}$ & $\begin{array}{c}-0.0498 \\
(0.153)\end{array}$ \\
\hline Dependent variable $_{t-1}$ & $\begin{array}{c}2.802^{* * *} \\
(0.231)\end{array}$ & $\begin{array}{c}2.630 * * * \\
(0.289)\end{array}$ & $\begin{array}{c}3.140 * * * \\
(0.379)\end{array}$ \\
\hline GDP (log) & $\begin{array}{c}0.380 \\
(0.675)\end{array}$ & $\begin{array}{l}-0.376 \\
(0.700)\end{array}$ & $\begin{array}{l}-8.959 \\
(9.030)\end{array}$ \\
\hline GDP per capita (log) & $\begin{array}{l}-0.363 \\
(0.680)\end{array}$ & $\begin{array}{c}0.320 \\
(0.719)\end{array}$ & $\begin{array}{c}9.065 \\
(8.998)\end{array}$ \\
\hline Exports $\mathrm{t}-1$ & $\begin{array}{l}-0.00337 \\
(0.00289)\end{array}$ & $\begin{array}{l}-0.00241 \\
(0.00290)\end{array}$ & $\begin{array}{l}-0.00169 \\
(0.00578)\end{array}$ \\
\hline Reserves in months of imports & $\begin{array}{l}-0.00291 \\
(0.0126)\end{array}$ & $\begin{array}{l}-0.0111 \\
(0.0229)\end{array}$ & $\begin{array}{l}-0.0205 \\
(0.0187)\end{array}$ \\
\hline Trade volatility & $\begin{array}{c}0.00332 \\
(0.00599)\end{array}$ & $\begin{array}{c}0.00199 \\
(0.00683)\end{array}$ & $\begin{array}{c}0.0168 \\
(0.0117)\end{array}$ \\
\hline Inflation $_{\mathrm{t}-1}$ & $\begin{array}{l}0.0360 \\
(0.125)\end{array}$ & $\begin{array}{c}-0.00153 \\
(0.159)\end{array}$ & $\begin{array}{l}0.0893 \\
(0.180)\end{array}$ \\
\hline Current account balance & $\begin{array}{c}-0.000754 \\
(0.00809)\end{array}$ & $\begin{array}{l}-0.00554 \\
(0.00776)\end{array}$ & $\begin{array}{c}0.0302 \\
(0.0227)\end{array}$ \\
\hline Capital account openness & $\begin{array}{c}0.0344 \\
(0.0341)\end{array}$ & $\begin{array}{c}0.0637 \\
(0.0426)\end{array}$ & $\begin{array}{c}-0.00415 \\
(0.0673)\end{array}$ \\
\hline Polity2 & $\begin{array}{c}0.0187 * * * \\
(0.00708)\end{array}$ & & \\
\hline Share of manufacturing $\mathrm{t}-1$ & $\begin{array}{c}0.00739 \\
(0.00887)\end{array}$ & $\begin{array}{l}0.00900 \\
(0.0108)\end{array}$ & $\begin{array}{c}-0.00307 \\
(0.0139)\end{array}$ \\
\hline Population $(\log ) \mathrm{t}-1$ & $\begin{array}{l}-0.344 \\
(0.683)\end{array}$ & $\begin{array}{c}0.381 \\
(0.720)\end{array}$ & $\begin{array}{l}9.039 \\
(9.030)\end{array}$ \\
\hline Constant cut1 & $\begin{array}{c}3.700 * * * \\
(1.302)\end{array}$ & $\begin{array}{c}0.771 \\
(1.567)\end{array}$ & $\begin{array}{c}6.800 * * * \\
(1.924)\end{array}$ \\
\hline Constant cut 2 & $\begin{array}{c}6.750 * * * \\
(1.346)\end{array}$ & $\begin{array}{c}3.695^{* *} \\
(1.581)\end{array}$ & $\begin{array}{c}10.14 * * * \\
(2.038)\end{array}$ \\
\hline Constant cut 3 & $\begin{array}{c}9.974 * * * \\
(1.437)\end{array}$ & $\begin{array}{c}6.594 * * * \\
(1.610)\end{array}$ & $\begin{array}{c}13.94 * * * \\
(2.269)\end{array}$ \\
\hline$\beta_{\text {remit }}+\beta_{\text {remit } x} C B I$ & $\begin{array}{l}\mathbf{0 . 1 1 0 *} \\
(0.061)\end{array}$ & $\begin{array}{c}\mathbf{0 . 2 6 1} * * * \\
(0.077) \\
\end{array}$ & $\begin{array}{l}-0.025 \\
(0.083) \\
\end{array}$ \\
\hline Observations & 1,313 & 815 & 498 \\
\hline Countries & 87 & 68 & 44 \\
\hline Pseudo R² & 0.702 & 0.669 & 0.741 \\
\hline Chi2 & 210.3 & 154 & 133.1 \\
\hline
\end{tabular}

Note: Robust standard errors clustered on country in parentheses. Statistical significance indicated as ${ }^{* * *} \mathrm{p}<0.01,{ }^{* *} \mathrm{p}<0.05,{ }^{*} \mathrm{p}<0.1$ 
In autocracies (column 2), the interaction term reveals that autocracies that receive remittances are more likely to have flexible exchange rates as CBI increases $\left(\beta_{3}>0\right)$. The combined coefficient $\left(\beta_{1}+\beta_{3}>0\right)$, which measures the marginal effect of remittances on the likelihood of having a floating exchange rate regime, and which appears at the bottom of Table 1 , is equally positive and significant. The results for democracies are the exact opposite in sign, albeit not statistically significant, which is consistent with our expectations.

Figure 2, based on column 2, provides support for our main hypothesis. Making CBI our conditioning variable, the marginal effect of remittances on the probability of observing a managed float (dotted line) is positive and statistically significant when the central bank is independent; that is, when $\mathrm{CBI} \geq 0.5$ (the common threshold for classifying central banks as independent). ${ }^{18}$ Conversely, the marginal effect of remittances on the probability of observing a fixed exchange rate is negative at similar levels of CBI, indicating a relationship between remittances and the substitution between fixed exchange rates and CBI. These effects are significantly different from each other when $\mathrm{CBI} \geq 0.5$, which corresponds to about $65 \%$ of autocracies and about $56 \%$ of autocracy-year observations in our sample of autocracies.

${ }^{18}$ We plot the effect on the probability of observing managed floats instead of free floating because there are very few observations in this category. Figure A2 in the appendix shows the marginal effect for each category of exchange rate regime. 
Figure 2. Marginal effect of remittances on the probability of observing a fixed exchange rate and a floating exchange rate as $\mathrm{CBI}$ increases

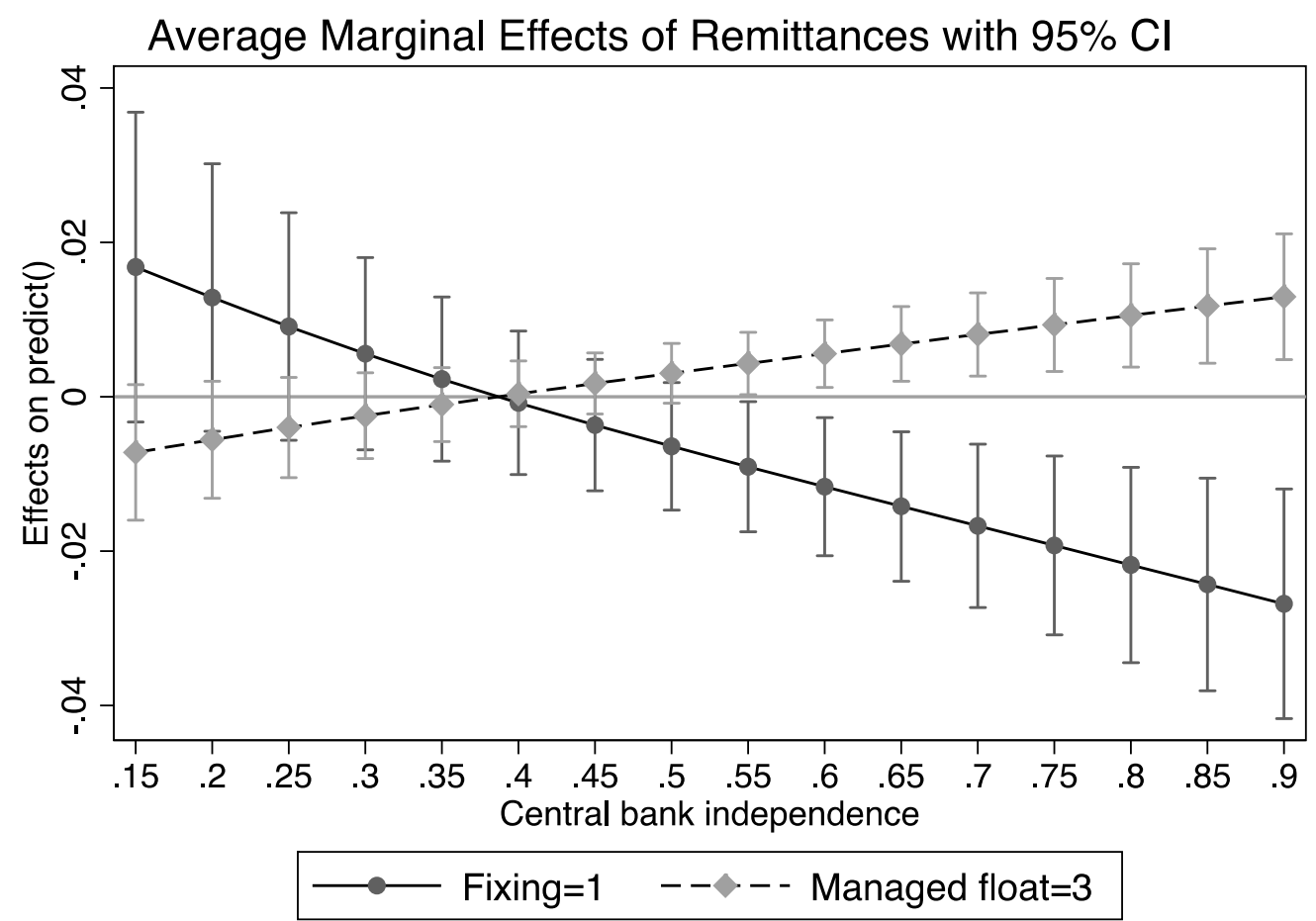

Our results do not support the alternative argument that by reducing the costs of adopting a fixed exchange rate, remittances increase the probability of pegging regardless of other monetary institutions in place (Singer 2010). As Figure 2 shows, in autocracies, once CBI is accounted for, the marginal effect of remittances on the probability of observing a peg - darkgrey line - is positive at very low levels of central bank independence $(\mathrm{CBI}<.33)$; but this effect is not statistically significant. 


\section{Robustness checks}

We run the following tests on the autocracies sub-sample. Consistent with the literature on exchange rate regimes, we did not include country fixed effects in the main models because about one third of the observations drop out when we do so. ${ }^{19}$ To control for unobserved sources of heterogeneity, we include regional fixed effects (see Model 4, Table 3). Even after losing observations belonging to one region, results hold.

${ }^{19}$ Using fixed effects is highly problematic because it removes from the estimations many countries with little variation in exchange rate regimes (Steinberg \& Malhotra, 2014). When we include country fixed effects in our probit estimation, the signs remain the same but the coefficients lose significance, most likely due to fewer observations in the sample (20 autocracies, 274 observations). 
Table 2. Robustness checks. Autocracies only

\begin{tabular}{|c|c|c|c|c|c|c|}
\hline Model & $\begin{array}{c}\text { (4) } \\
\text { Region FE }\end{array}$ & $\begin{array}{c}(5) \\
\text { Jackknife }\end{array}$ & $\begin{array}{c}(6) \\
\text { Time }\end{array}$ & $\begin{array}{c}(7) \\
5 \text { Yr Lags }\end{array}$ & $\begin{array}{c}(8) \\
\text { GMM }\end{array}$ & $\begin{array}{c}(9) \\
\text { IVProbit }\end{array}$ \\
\hline Central Bank Independence $t-1$ & $\begin{array}{c}-7.814 * * * \\
(2.444)\end{array}$ & $\begin{array}{c}-7.254 * * * \\
(2.678)\end{array}$ & $\begin{array}{c}-8.519 * * \\
(3.682)\end{array}$ & $\begin{array}{c}-6.039 * * \\
(3.024)\end{array}$ & $\begin{array}{c}-2.571^{* *} \\
(0.991)\end{array}$ & $\begin{array}{c}-2.659 * * \\
(1.079)\end{array}$ \\
\hline Remittances $_{\mathrm{t}-1} * \mathrm{CBI}_{\mathrm{t}-1}$ & $\begin{array}{c}0.465^{* * *} * \\
(0.146)\end{array}$ & $\begin{array}{c}0.425^{* *} \\
(0.167)\end{array}$ & $\begin{array}{l}0.446^{*} \\
(0.229)\end{array}$ & $\begin{array}{l}0.344^{*} \\
(0.192)\end{array}$ & $\begin{array}{c}0.179 * * \\
(0.0707)\end{array}$ & $\begin{array}{c}0.647 * * * \\
(0.241)\end{array}$ \\
\hline GDP(log) & $\begin{array}{l}-1.235 \\
(0.901)\end{array}$ & $\begin{array}{l}-0.376 \\
(0.945)\end{array}$ & $\begin{array}{c}-4.085^{* *} \\
(1.798)\end{array}$ & $\begin{array}{l}-1.074 \\
(0.995)\end{array}$ & $\begin{array}{c}0.591 \\
(0.991)\end{array}$ & $\begin{array}{c}0.439 \\
(2.395)\end{array}$ \\
\hline GDP per capita (log) & $\begin{array}{c}1.331 \\
(0.937)\end{array}$ & $\begin{array}{c}0.320 \\
(0.964)\end{array}$ & $\begin{array}{c}3.941 * * \\
(1.828)\end{array}$ & $\begin{array}{c}1.078 \\
(1.018)\end{array}$ & $\begin{array}{l}-0.615 \\
(0.996)\end{array}$ & $\begin{array}{l}-0.304 \\
(2.384)\end{array}$ \\
\hline Exports $_{\mathrm{t}-1}$ & $\begin{array}{c}-0.00724^{*} \\
(0.00426)\end{array}$ & $\begin{array}{l}-0.00241 \\
(0.00363)\end{array}$ & $\begin{array}{c}0.00209 \\
(0.00595)\end{array}$ & $\begin{array}{l}-0.00274 \\
(0.00344)\end{array}$ & $\begin{array}{l}0.000608 \\
(0.00198)\end{array}$ & $\begin{array}{c}0.00285 \\
(0.00452)\end{array}$ \\
\hline Inflation $(\log ) \mathrm{t}-1$ & $\begin{array}{c}0.122 \\
(0.190)\end{array}$ & $\begin{array}{c}-0.00153 \\
(0.173)\end{array}$ & $\begin{array}{c}0.835^{* * *} \\
(0.250)\end{array}$ & $\begin{array}{c}0.124 \\
(0.179)\end{array}$ & $\begin{array}{l}-0.0697 \\
(0.0978)\end{array}$ & $\begin{array}{l}0.0235 \\
(0.211)\end{array}$ \\
\hline Current account balance & $\begin{array}{l}-0.00312 \\
(0.00750)\end{array}$ & $\begin{array}{l}-0.00554 \\
(0.00909)\end{array}$ & $\begin{array}{l}-0.00669 \\
(0.00929)\end{array}$ & $\begin{array}{l}-0.00959 \\
(0.00884)\end{array}$ & $\begin{array}{l}0.000296 \\
(0.00219)\end{array}$ & $\begin{array}{l}0.00373 \\
(0.0172)\end{array}$ \\
\hline Capital account openness & $\begin{array}{c}0.0517 \\
(0.0522)\end{array}$ & $\begin{array}{c}0.0637 \\
(0.0503)\end{array}$ & $\begin{array}{c}0.0321 \\
(0.0787)\end{array}$ & $\begin{array}{c}0.0768 \\
(0.0555)\end{array}$ & $\begin{array}{c}0.0324 \\
(0.0223)\end{array}$ & $\begin{array}{r}-0.205^{* *} \\
(0.0809)\end{array}$ \\
\hline Share of manufacturing ${ }_{t-1}$ & -0.00748 & 0.00900 & -0.0154 & 0.0136 & 0.00642 & 0.0221 \\
\hline
\end{tabular}




\begin{tabular}{|c|c|c|c|c|c|c|}
\hline Model & $\begin{array}{c}\text { (4) } \\
\text { Region FE }\end{array}$ & $\begin{array}{c}\text { (5) } \\
\text { Jackknife }\end{array}$ & $\begin{array}{c}\text { (6) } \\
\text { Time }\end{array}$ & $\begin{array}{c}(7) \\
5 \text { Yr Lags }\end{array}$ & $\begin{array}{c}(8) \\
\text { GMM }\end{array}$ & $\begin{array}{c}(9) \\
\text { IVProbit }\end{array}$ \\
\hline & $(0.0151)$ & $(0.0141)$ & $(0.0189)$ & $(0.0134)$ & $(0.00692)$ & $(0.0163)$ \\
\hline \multirow{2}{*}{ Population $(\log )_{\mathrm{t}-1}$} & 1.217 & 0.381 & $4.095^{* *}$ & 1.061 & -0.634 & -0.329 \\
\hline & $(0.938)$ & $(0.964)$ & (1.818) & $(1.016)$ & $(0.987)$ & $(2.413)$ \\
\hline \multirow{2}{*}{$\beta_{\text {remit }}+\beta_{\text {remit } x}$ CBI } & $.331 * * *$ & $.261 * * *$ & $0.362 * * *$ & $0.227 * *$ & $.109 * * *$ & $.303 * * *$ \\
\hline & $(.091)$ & $(.092)$ & $(0.130)$ & $(0.105)$ & $(0.033)$ & $(0.113)$ \\
\hline Observations & 624 & 815 & 824 & 666 & 815 & 815 \\
\hline Countries & 54 & 68 & 69 & 63 & 68 & 68 \\
\hline Pseudo $\mathrm{R}^{2}$ & 0.655 & 0.669 & & 0.646 & & \\
\hline \multicolumn{7}{|l|}{$\begin{array}{l}\text { Arellano-Bond test for } \mathrm{AR} \text { in first } \\
\text { differences ( } z \text { value) }\end{array}$} \\
\hline $\operatorname{AR}(1)$ & & & & & $-2.70 * * *$ & \\
\hline AR (2) & & & & & 0.71 & \\
\hline \multicolumn{7}{|l|}{$\begin{array}{l}\text { Test of overriding } \\
\text { restrictions:chi2(61) }\end{array}$} \\
\hline Sargan & & & & & 38.25 & \\
\hline Hansen & & & & & 44.60 & \\
\hline Wald Test of Exogeneity ( $\not$ value) & & & & & & 0.6763 \\
\hline
\end{tabular}

Note: Robust standard errors clustered on country in parentheses. Robust standard errors in Column 8 are not clustered, constant omitted. Statistical significance indicated as $* * * \mathrm{p}<0.01,{ }^{* *} \mathrm{p}<0.05, * \mathrm{p}<0.1$. In column 4 , regional effects are included but not reported. In Column 7 , the interaction is with remittances lagged 5 years, and CBI is lagged 5 years as well. In column 9 , we use remittances as $\%$ of GDP. 
A second concern is the sensitivity of our results to outlier cases. We run both jackknife estimations (Model 5) and a cross-validation test on the sample of autocracies. We did not find any case driving the main finding. ${ }^{20}$ In Model 6, we present the results excluding the lagged dependent variable and including instead cubic time polynomials to control for time dependence. This modification does not change our results substantively.

A series of concerns relate to endogeneity problems. Exchange rate regimes may affect the patterns of remittance-sending - in other words, exchange rates are likely to determine remittances by affecting migrants' decisions to remit - creating a problem of reverse causality (Panda \& Trivedi, 2015; Vargas-Silva, 2009). It is also possible that measurement error in the remittances variable causes biases in our estimations, or that we are not capturing some omitted variable that is influencing both remittances and the choice of exchange rates. To address these issues, we employ several strategies. First, we lag remittances by 5 years (Model 7). Second, we run generalized methods of moments (GMM) dynamic panel data models (Arellano \& Bond, 1991; Arellano \& Bover, 1995; Blundell \& Bond, 1998). ${ }^{21}$ In spite of its challenges, this strategy tackles the issues of joint

${ }^{20}$ Cross-validation is a leave-one-out method that helps to detect countries that do not fit the model. First, the model is estimated leaving one country out of the sample; second, the estimated parameters are taken to predict the data of the country that has not been used, and the mean absolute error is calculated for that country; third, the individual value is compared with the mean absolute error of the sample. We do not find any case in which the difference in absolute terms between the individual and the mean absolute error is problematic.

${ }^{21}$ Arellano-Bond type models are problematic because the number of instruments can become too large for the sample size (Roodman, 2009). We use short lags to overcome these issues. 
endogeneity of all explanatory variables in a dynamic formulation (Model 8). ${ }^{22}$ Our main findings hold.

Additionally, we use an instrumental variable approach. We instrument remittances with the GDP per capita in the top ten rich migration destination countries of the world, weighted by the inverse of the distance of each developing nation to the top ten destination countries. Formally, the instrumental variable $\mathrm{Z}_{\mathrm{i}, \mathrm{t}}$ for developing country $i$ in year $t$ can be written as:

$$
Z_{i, t}=\sum_{j=1}^{10} \frac{\text { GDPpercapita }_{j, t}}{\text { distance }_{i, j}}
$$

where distance $\mathrm{ij}_{\mathrm{ij}}$ refers to the distance between country $i$ and destination country $j$, and

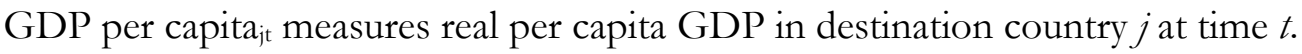

The ten largest host countries for migrants in 1990 were the United States, Russia, Germany, France, Saudi Arabia, Canada, Australia, United Kingdom, Israel, and Kuwait (UN Population Division, Department of Economic and Social Affairs).$^{23}$ Distance comes from the GeoDist database. ${ }^{24}$ Finally, annual income per capita data comes from the WDI (World Bank, 2015). This variable performs well in predicting remittances as percent of GDP, but is a poor instrument for predicting remittances in constant USD, which is the variable we have used in the main models. Nonetheless, since our results are robust to different specifications of the dependent variable (see Table A3, Supplementary Appendix),

${ }^{22}$ Both Sargan and Hansen tests of overriding restrictions fail to reject the null hypothesis (H0: overidentifying restrictions are valid). Similarly, the difference-in-Hansen tests of exogeneity of instrument subsets fail to reject the null, suggesting that the instruments are exogenous.

${ }^{23}$ http://www.un.org/en/development/desa/population/migration/data/estimates2/estimatesorigin. $\underline{\text { shtml }}$

${ }^{24}$ http://www.cepii.fr/cepii/en/bdd_modele/presentation.asp?id=6 
we consider this test informative for addressing the robustness of our results. In the sample of autocracies, remittances over GDP and the instrument are strongly correlated (0.60).

Model 9 shows the results of the second stage IV probit estimation - after dichotomizing the dependent variable, so that categories 1 and 2 are coded 0 (fixed exchange rates) and categories 3 and 4 are coded 1 (flexible exchange rates), confirming the results in the main models: remittances increase the likelihood of observing a fixed exchange rate at low levels of central bank independence, but as $\mathrm{CBI}$ increases the probability of observing a fixed exchange rate decreases in favour of more flexible exchange rate arrangements. Note, however, that the Wald Test of exogeneity suggests that the pooled probit estimation is preferred.

In the Supplementary Appendix, we show further robustness tests. First, our results hold when we replicate Table 1 using different measures of our dependent and main independent variable (remittances). In Table A3, we measure remittances as a ratio of GDP and in per capita terms . In both cases, our main result holds. The results also hold when we dichotomize the dependent variable into fixed and flexible exchange rates as explained above. This reduces concerns about the effect that movements within the main categories could have on our results - that is, that our theory mainly applies to marginal changes between fixed exchange rates and crawling pegs, or between managed floats and freefloating regimes. These results are reported in Table A4.

\section{Conclusions}

We address one consequence of globalization on domestic politics: the effect of growing capital movements associated with international migration. We focus on developing countries, and analyse how remittances affect the choice of exchange rate regimes. We theorize and find that the relationship between remittances and exchange rate regime 
choices is highly dependent on the political and monetary institutions in the recipient countries. In fact, we propose that different channels may link remittances and exchange rate regimes depending on domestic institutions. We show that within the constraints imposed by the trilemma, remittances open up policy options for less democratic countries in the developing world.

In our view, political and monetary institutions need to be explicitly considered to understand why some governments have no choice but to adopt fixed exchange rates, while others have more freedom to choose exchange rates. We look at two crucial conditioning variables: political regimes and central bank independence. More concretely, we argue and show that remittances have different effects on exchange rate regime choices, depending on how credible monetary commitments are. Holding other things constant, remittances can make delegation to central banks credible in less-transparent regimes because they curb the incentives to use monetary policy counter-cyclically, enhancing autocracies' capacity to honour price stability commitments. In this way, remittances allow the substitution of fixed exchange rate regimes by independent central banks as mechanisms of commitment to monetary discipline.

It is possible that some remittance-recipient autocracies with independent central banks are still willing to adopt or maintain fixed exchange rates. We interpret these cases as situations that the literature frames as "fear of floating" (Calvo \& Reinhart, 2002; LevyYeyati \& Sturzenegger, 2005), which may respond to domestic pressures, in the case of democracies, or to very serious credibility issues, in the case of autocracies.

Finally, note that our analysis looks at how levels of remittances interact with political regimes and monetary institutions to affect the probability of observing different exchange rate regimes. A next step in this research agenda will explore how changes in remittances may equally affect the choices of exchange rate regimes. While our argument has so far rested on the well-documented stable and anti-cyclical character of remittances, 
changes in economic conditions in destination countries may trigger a fall in remittances sent back home. We consider that exploring these dynamic effects will also imply giving serious attention to the role of central bank independence as a mediating factor in the decision to transition to more flexible exchange rates. 


\section{References}

Abdih, Y., Chami, R., Dagher, J., \& Montiel, P. (2012). Remittances and Institutions: Are Remittances a Curse? World Development, 40(4), 657-666. doi:https://doi.org/10.1016/j.worlddev.2011.09.014

Adams, R. H., \& Cuecuecha, A. (2010). Remittances, Household Expenditure and Investment in Guatemala. World Development, 38(11), 1626-1641. doi:http://dx.doi.org/10.1016/j.worlddev.2010.03.003

Adams, R. H., \& Page, J. (2005). Do International Migration and Remittances Reduce Poverty in Developing Countries? World Development, 33(10), 1645-1669. doi:http://dx.doi.org/10.1016/i.worlddev.2005.05.004

Adida, C. L., \& Girod, D. M. (2011). Do Migrants Improve Their Hometowns? Remittances and Access to Public Services in Mexico, 1995-2000. Comparative Political Studies, 44(1), 3-27. doi:10.1177/0010414010381073

Ahmed, F. Z. (2012). The Perils of Unearned Foreign Income: Aid, Remittances, and Government Survival. American Political Science Review, 106(1), 146-165. doi:10.1017/S0003055411000475

Ahmed, F. Z. (2013). Remittances Deteriorate Governance. The Review of Economics and Statistics, 95(4), 1166-1182. doi:10.1162/REST_a_00336

Aizenman, Joshua. 2018. "A modern reincarnation of Mundell-Fleming's trilemma." Economic Modelling. Available online 15 March. https://doi.org/10.1016/j.econmod.2018.03.008

Aparicio, F. J., \& Meseguer, C. (2012). Collective Remittances and the State: The $3 \times 1$ Program in Mexican Municipalities. World Development, 40(1), 206-222. doi:http://dx.doi.org/10.1016/j.worlddev.2011.05.016

Arellano, M., \& Bond, S. (1991). Some Tests of Specification for Panel Data: Monte Carlo Evidence and an Application to Employment Equations. The Review of Economic Studies, 58(2), 277-297.

Arellano, M., \& Bover, O. (1995). Another Look at the Instrumental Variable Estimation of Error-Components Models. Journal of Econometrics, 68(1), 29-51. doi:http://dx.doi.org/10.1016/0304-4076(94)01642-D

Avendano, R., Gaillard, N., \& Nieto-Parra, S. (2011). Are Working Remittances Relevant for Credit Rating Agencies? Review of Development Finance, 1(1), 57-78. doi:http://dx.doi.org/10.1016/j.rdf.2010.10.003

Baerg, N. R., Gray, J., \& Willisch, J. (2017). They Could Have Been Contenders: A Power-Sharing Explanation for Central Bank Independence in Transition Countries. Paper presented at the 2017 American Political Science Association Annual Meeting, August 31September 3, 2017, San Francisco, CA.

Banaian, K., Kemme, D. M., \& Sargsyan, G. (2008). Inflation Targeting in Armenia: Monetary Policy in Transition. Comparative Economic Studies, 50(3), 421-437. doi:10.1057/ces.2008.22

Barajas, A., Chami, R., Ebeke, C., \& Oeking, A. (2016). What's Different about Monetary Policy Transmission in Remittance-Dependent Countries? Retrieved from Washington, D.C.: file:///Users/CarolinaGarriga/Downloads/_wp1644.pdf

Bearce, D. H. (2002). Monetary Divergence: Domestic Political Institutions and the Monetary Autonomy-Exchange Rate Stability Trade-off. Comparative Political Studies, 35(2), 194-220.

Bearce, D. H. (2008). Not Complements, But Substitutes: Fixed Exchange Rate Commitments, Central Bank Independence, and External Currency Stability. International Studies Quarterly, 52(4), 807-824. 
Bearce, D. H. (2014). A Political Explanation for Exchange-Rate Regime Gaps. The Journal of Politics, 76(01), 58-72. doi:doi:10.1017/S0022381613001047

Bearce, D. H., \& Hallerberg, M. (2011). Democracy and de Facto Exchange Rate Regimes. Economics \& Politics, 23(2), 172-194. doi:10.1111/j.1468-0343.2011.00381.x

Bearce, D. H., \& Tuxhorn, K.-L. (2017). When Are Monetary Policy Preferences Egocentric? Evidence from American Surveys and an Experiment. American Journal of Political Science, 61(1), 178-193. doi:10.1111/ajps.12203

Bermeo, S. B., \& Leblang, D. (2015). Migration and Foreign Aid. International Organization, 69(3), 627-657. doi:10.1017/S0020818315000119

Bernhard, W., Broz, J. L., \& Clark, W. R. (2002). The Political Economy of Monetary Institutions. International Organization, 56(4, The Political Economy of Monetary Institutions), 693-723.

Blundell, R., \& Bond, S. (1998). Initial Conditions and Moment Restrictions in Dynamic Panel Data Models. Journal of Econometrics, 87(1), 115-143. doi:http://dx.doi.org/10.1016/S0304-4076(98)00009-8

Bodea, C. (2010). Exchange Rate Regimes and Independent Central Banks: A Correlated Choice of Imperfectly Credible Institutions. International Organization, 64(3), 411442.

Bodea, C., Garriga, A. C., \& Higashijima, M. (2019). Economic Institutions and Autocratic Breakdown: Monetary Constraints and Fiscal Spending in Dominant-Party Regimes. Journal of Politics, 81(2), 601-615

Bodea, C., \& Hicks, R. (2015a). International Finance and Central Bank Independence: Institutional Diffusion and the Flow and Cost of Capital. Journal of Politics, 77(1), 268-284.

Bodea, C., \& Hicks, R. (2015b). Price Stability and Central Bank Independence: Discipline, Credibility, and Democratic Institutions. International Organization, 69(01), 35-61. doi:doi:10.1017/S0020818314000277

Boylan, D. M. (1998). Preemptive Strike: Central Bank Reform in Chile's Transition from Authoritarian Rule. Comparative Politics, 30(4), 443-462.

Boylan, D. M. (2001). Defusing Democracy. Ann Arbor, MI: University of Michigan Press.

Broz, J. L. (2002). Political System Transparency and Monetary Commitment Regimes. International Organization, 56(4), 861-887.

Bugamelli, Matteo and Francesco Paterno. 2009. “Do Workers' Remittances Reduce the Probability of Current Account Reversals?" World Development Vol. 37(12): 1821_ 1838.

Calvo, G. A., \& Reinhart, C. M. (2002). Fear of Floating. The Quarterly Journal of Economics, 117(2), 379-408. doi:10.1162/003355302753650274

Chami, R., Barajas, A., Cosimano, T., Fullenkamp, C., Gapen, M., \& Montiel, P. (2008). Macroeconomic Consequences of Remittances. Occasional Paper 259. International Monetary Fund: Washington, D.C.

Chinn, M., \& Ito, H. (2008). A New Measure of Financial Openness. Journal of Comparative Policy Analysis, 10(3), 309-322.

Chiu, E. M. P., \& Willett, T. D. (2009). The Interactions of Strength of Governments and Alternative Exchange Rate Regimes in Avoiding Currency Crises. International Studies Quarterly, 53(4), 1001-1025.

Clark, W. R. (2002). Partisan and Electoral Motivations and the Choice of Monetary Institutions under Fully Mobile Capital. International Organization, 56(4), The Political Economy of Monetary Institutions), 725-749.

Combes, J.-L., \& Ebeke, C. (2011). Remittances and Household Consumption Instability in Developing Countries. World Development, 39(7), 1076-1089. doi:http://dx.doi.org/10.1016/j.worlddev.2010.10.006 
Combes, J.-L., Ebeke, C., \& Maurel, M. (2015). The Effect of Remittances Prior to an Election. Applied Economics, 47(38), 4074-4089. doi:10.1080/00036846.2015.1023945

Cukierman, A., Webb, S. B., \& Neyapti, B. (1992). Measuring the Independence of Central Banks and Its Effect on Policy Outcome. The World Bank Economic Review, 6(1), 353398.

Dion, M. (2009). Globalization, Democracy, and Mexican Welfare, 1988-2006. Comparative Politics, 49(1), 63-82.

Doyle, D. (2015). Remittances and Social Spending. American Political Science Review, 109(04), 785-802. doi:doi:10.1017/S0003055415000416

Duquette-Rury, L. (2014). Collective Remittances and Transnational Coproduction: the $3 \times 1$ Program for Migrants and Household Access to Public Goods in Mexico. Studies in Comparative International Development, 49(1), 112-139. doi:10.1007/s12116014-9153-3

Easton, M. R., \& Montinola, G. R. (2017). Remittances, Regime Type, and Government Spending Priorities. Studies in Comparative International Development, 52(3): 349-371.

Ebeke, C. H. (2012). Do Remittances Lead to a Public Moral Hazard in Developing Countries? An Empirical Investigation. The Journal of Development Studies, 48(8), 1009-1025. doi:10.1080/00220388.2011.615918

Ebeke, C. H. (2014). Do International Remittances Affect the Level and the Volatility of Government Tax Revenues? . Journal of International Development, 26(7), 1039-1053. doi:doi:10.1002/jid.2979

Ebeke, C. H., \& Drabo, A. (2011). Remittances, Public Health Spending and Foreign Aid in the Access to Health Care Services in Developing Countries. Etudes et Documents du CERDI.

Escribà-Folch, A., Meseguer, C., \& Wright, J. (2015). Remittances and Democratization. International Studies Quarterly, 59(3), 571-586. doi:10.1111/isqu.12180

Fajnzylber, P., \& López, J. H. (2008). The Development Impact of Remittances in Latin America. In Fajnzylber, P., \& López, J. H.(editors). Remittances and Development. Lessons from Latin America. The World Bank: Washington DC. Pp 1-20.

Duttagupta, R., Fernandez, G., \& Karacadag, C.(2004). From Fixed to Float: Operational Aspects of Moving towards Exchange Rate Flexibility. IMF Working Paper WP/04/126 International Monetary Fund: Washington, D.C.

Fleming, J. M. (1962). Domestic Financial Policies Under Fixed and Floating Exchange Rates. IMF Staff Papers, 9(3), 369-380.

Frankel, J. (2011). Are Bilateral Remittances Countercyclical? Open Economies Review, 22(1), $1-16$.

Frieden, J. A. (1991). Invested Interests: The Politics of National Economic Policies in a World of Global Finance. International Organization, 45(4), 425-451.

Frieden, J. A. (2015). Currency Politics: The Political Economy of Exchange Rate Policy. Princeton, NJ: Princeton University Press.

Garrett, G., \& Lange, P. (1991). Political Responses to Interdependence: What's "Left" for the Left? International Organization, 45(4), 539-564.

Gnangnon, Sena K. (2014)."The effect of Development Aid Unpredictability and Migrants' Remittances on Fiscal consolidation in Developing Countries." World Development, 54: 168-190.

Garriga, A. C. (2016). Central Bank Independence in the World: A New Data Set. International Interactions, 42(5), 849-868.

Johnson, J. (2016). Priests of Prosperity. Ithaca, NY: Cornell University Press.

Leblang, D. (2003). To Devalue or to Defend? The Political Economy of Exchange Rate Policy. International Studies Quarterly, 47(4), 533-560. doi:10.1046/j.0020-

8833.2003.00278.x 
Leblang, D. (2010). Familiarity Breeds Investment: Diaspora Networks and International Investment. American Political Science Review, 104(3), 584-600.

Leblang, D. (2017). Harnessing the Diaspora: Dual Citizenship, Migrant Return Remittances. Comparative Political Studies, 50(1):75-101 doi:10.1177/0010414015606736

Levy-Yeyati, E., \& Sturzenegger, F. (2005). Classifying Exchange Rate Regimes: Deeds vs. Words. European Economic Review, 49(6), 1603-1635.

Lim, S \& Morshed, A.K.M . (2017). Fiscal Policy in a Small Open Economy with CrossBorder Labour Mobility. Journal of Macroeconomics, 52: 147-174.

Mandelman, F. S. (2013). Monetary and Exchange Rate Policy under Remittance Fluctuations. Journal of Development Economics, 102, 128-147. doi:http://dx.doi.org/10.1016/j.jdeveco.2012.02.006

Marshall, M. G., \& Jaggers, K. (2012). Polity IV Dataset.

Maxfield, S. (1997). Gatekeepers of Growth: The International Political Economy of Central Banking in Developing Countries. Princeton, NJ: Princeton University Press.

McMann, K. M. (2006). Economic Autonomy and Democracy: Hybrid Regimes in Russia and Kyrgyzstan: Cambridge University Press.

McNamara, K. (2002). Rational Fictions: Central Bank Independence and the Social Logic of Delegation. West European Politics, 25(1), 47-76. doi:10.1080/713601585

Meissner, C. M., \& Oomes, N. (2009). Why Do Countries Peg the Way They Peg? The Determinants of Anchor Currency Choice. Journal of International Money and Finance, 28(3), 522-547. doi:http://dx.doi.org/10.1016/i.jimonfin.2008.08.007

Mundell, R. A. (1961). A Theory of Optimum Currency Areas. American Economic Review, 51(4), 657-665.

Ncube, M., \& Brixiova, Z. (2013). Remittances and their Macroeconomic Impact: Evidence from Africa. Working Paper Series. African Development Bank Group

Obstfeld, M., \& Rogoff, K. (1995). The Mirage of Fixed Exchange Rates. The Journal of Economic Perspectives, 9(4), 73-96.

Obstfeld, M., Shambaugh, J. C., \& Taylor, A. M. (2005). The Trilemma in History: Tradeoffs among Exchange Rates, Monetary Policies, and Capital Mobility. Review of Economics and Statistics, 87(3), 423-438.

Panda, D. P., \& Trivedi, P. (2015). Macroeconomic Determinants of Remittances: A Cross Country Analysis. Journal of International Economics, 6(2), 83.

Reinhart, C. M., \& Rogoff, K. S. (2004). The Modern History of Exchange Rate Arrangements: A Reinterpretation. Quarterly Journal of Economics, 119 (1), 1-48.

Rey, H. (2015). Dilemma Not Trilemma: The Global Financial Cycle and Monetary Policy Independence. Retrieved from

Rey, H. (2016). International Channels of Transmission of Monetary Policy and the Mundellian Trilemma. IMF Economic Review, 64(1), 6-35. doi:10.1057/imfer.2016.4

Rogoff, K., Husain, A., Mody, A., Brooks, R., \& Oomes, N. (2003). Evolution and Performance of Exchange Rate Regimes. Working Paper WP/03/243. International Monetary Fund: Washington, D.C.

Roodman, D. (2009). How to Do xtabond2: An Introduction to "Difference" and "System" GMM in Stata. The Stata Journal, 9(1), 86-136.

Rudra, N. (2002). Globalization and the Decline of the Welfare State in Less Developed Countries. International Organization, 56(2), 411-445.

Ruiz, I., \& Vargas-Silva, C. (2010). Monetary Policy and International Remittances. The Journal of Developing Areas, 43(2), 173-186.

Simmons, B., \& Hainmueller, J. (2005). Can Domestic Institutions Explain Exchange Rate Regime Choice? The Political Economy of Monetary Institutions Reconsidered. International Finance, 505011. 
Singer, D. A. (2010). Migrant Remittances and Exchange Rate Regimes in the Developing World. American Political Science Review, 104(02), 307-323. doi:doi:10.1017/S0003055410000110

Steinberg, D. A., \& Malhotra, K. (2014). The Effect of Authoritarian Regime Type on Exchange Rate Policy. World Politics, 66(03), 491-529. doi:doi:10.1017/S0043887114000136

Tyburski, M. D. (2012). The Resource Curse Reversed? Remittances and Corruption in Mexico1. International Studies Quarterly, 56(2), 339-350. doi:10.1111/j.14682478.2012.00721.x

Tyburski, M. D. (2014). Curse or Cure? Migrant Remittances and Corruption. The Journal of Politics, 76(3), 814-824. doi:doi:10.1017/S0022381614000279

Van Aarle, B., \& Sosoian, R. (2010). Macroeconomic Adjustment in Armenia: The Role of External Factors. Journal of Business and Economics, 3(5), 51-75.

Vargas-Silva, C. (2009). The Tale of Three Amigos: Remittances, Exchange Rates, and Money Demand in Mexico. Review of Development Economics, 13(1), 1-14. doi:10.1111/j.1467-9361.2008.00468.x

World Bank. (2006). Global Economic Prospects: Economic Implications of Remittances and Migration. Retrieved from Washington, D.C.:

World Bank. (2015). World Development Indicators On-Line. from World Bank

World Bank. (2017). Trends in Migration and Remittances. Retrieved from http://www.worldbank.org/en/news/infographic/2017/04/21/trends-inmigration-and-remittances-2017

Yang, D., \& Choi, H. (2007). Are Remittances Insurance? Evidence from Rainfall Shocks in the Philippines. The World Bank Economic Review, 21(2), 219-248. 